\title{
Front Matter: Volume 8852
}

, "Front Matter: Volume 8852," Proc. SPIE 8852, Hard X-Ray, Gamma-Ray, and Neutron Detector Physics XV, 885201 (8 October 2013); doi:

$10.1117 / 12.2045822$

SPIE Event: SPIE Optical Engineering + Applications, 2013, San Diego, California, SPIE. United States 


\title{
PROCEEDINGS OF SPIE
}

\section{Hard X-Ray, Gamma-Ray, and Neutron Defector Physics XV}

\author{
Michael Fiederle \\ Arnold Burger \\ Larry Franks \\ Ralph B. James \\ Editors
}

\section{6-28 August 2013}

San Diego, California, United States

Sponsored and Published by

SPIE 
The papers included in this volume were part of the technical conference cited on the cover and title page. Papers were selected and subject to review by the editors and conference program committee. Some conference presentations may not be available for publication. The papers published in these proceedings reflect the work and thoughts of the authors and are published herein as submitted. The publisher is not responsible for the validity of the information or for any outcomes resulting from reliance thereon.

Please use the following format to cite material from this book:

Author(s), "Title of Paper," in Hard X-Ray, Gamma-Ray, and Neutron Detector Physics XV, edited by Michael Fiederle, Arnold Burger, Larry Franks, Ralph B. James, Proceedings of SPIE Vol. 8852 (SPIE, Bellingham, WA, 2013) Article CID Number.

ISSN: 0277-786X

ISBN: 9780819497024

Published by

SPIE

P.O. Box 10, Bellingham, Washington 98227-0010 USA

Telephone +1 3606763290 (Pacific Time) · Fax +1 3606471445

SPIE.org

Copyright @ 2013, Society of Photo-Optical Instrumentation Engineers.

Copying of material in this book for internal or personal use, or for the internal or personal use of specific clients, beyond the fair use provisions granted by the U.S. Copyright Law is authorized by SPIE subject to payment of copying fees. The Transactional Reporting Service base fee for this volume is $\$ 18.00$ per article (or portion thereof), which should be paid directly to the Copyright Clearance Center (CCC), 222 Rosewood Drive, Danvers, MA 01923. Payment may also be made electronically through CCC Online at copyright.com. Other copying for republication, resale, advertising or promotion, or any form of systematic or multiple reproduction of any material in this book is prohibited except with permission in writing from the publisher. The CCC fee code is 0277-786X/13/\$18.00.

Printed in the United States of America.

Publication of record for individual papers is online in the SPIE Digital Library.

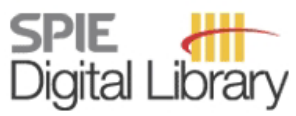

SPIEDigitalLibrary.org

Paper Numbering: Proceedings of SPIE follow an e-First publication model, with papers published first online and then in print and on CD-ROM. Papers are published as they are submitted and meet publication criteria. A unique, consistent, permanent citation identifier (CID) number is assigned to each article at the time of the first publication. Utilization of CIDs allows articles to be fully citable as soon as they are published online, and connects the same identifier to all online, print, and electronic versions of the publication. SPIE uses a six-digit CID article numbering system in which:

- The first four digits correspond to the SPIE volume number.

- The last two digits indicate publication order within the volume using a Base 36 numbering

system employing both numerals and letters. These two-number sets start with 00, 01, 02, 03, 04, $05,06,07,08,09,0 A, 0 B \ldots 0 Z$, followed by 10-1Z, 20-2Z, etc.

The CID Number appears on each page of the manuscript. The complete citation is used on the first page, and an abbreviated version on subsequent pages. Numbers in the index correspond to the last two digits of the six-digit CID Number. 


\section{Contents}

ix Conference Committee

xi Introduction

\section{SCINTILLATORS I}

885203 Time-encoded imaging of energetic radiation [8852-2]

J. Brennan, E. Brubaker, M. Gerling, P. Marleau, A. Nowack, P. Schuster, Sandia National Labs. (United States)

885205 First-principles study of electronic structure, defects, and activators in LiCaAlF 6 [8852-4] M.-H. Du, D. J. Singh, Oak Ridge National Lab. (United States)

\section{DETECTOR MATERIALS}

$88520 \mathrm{~A}$ Heavy metal ternary halides for room-temperature $\mathrm{x}$-ray and gamma-ray detection [8852-9]

Z. Liu, J. A. Peters, Northwestern Univ. (United States); C. C. Stoumpos, Northwestern Univ. (United States) and Argonne National Lab. (United States); M. Sebastian, B. W. Wessels, J. Im, A. J. Freeman, Northwestern Univ. (United States); M. G. Kanatzidis, Northwestern Univ. (United States) and Argonne National Lab. (United States)

8852 OB Basic studies on $x$-ray fluorescence analysis for active $x$-ray spectrometer on SELENE-2 [8852-10]

H. Kusano, N. Hasebe, H. Nagaoka, T. Kodama, Y. Oyama, R. Tanaka, Y. Amano, Waseda Univ. (Japan); K. J. Kim, Korea Institute of Geoscience and Mineral Resources (Korea, Republic of); J. A. Matias Lopes, Univ. de Coimbra (Portugal) and Instituto Superior de Engenharia de Coimbra (Portugal)

8852 OD Fabrication of high resolution n-type 4H-SiC epitaxial layer alpha particle detectors, defect characterization and electronic noise analysis [8852-12]

K. J. Zavalla, S. K. Chaudhuri, K. C. Mandal, Univ. of South Carolina (United States)

8852 OE Photoemission analysis of chemically modified TIBr surfaces for improved radiation detectors [8852-13]

A. J. Nelson, Lawrence Livermore National Lab. (United States); J.-S. Lee, SLAC National Accelerator Lab. (United States); J. A. Stanford, W. K. Grant, L. F. Voss, P. R. Beck, R. T. Graff, E. L. Swanberg, A. M. Conway, R. J. Nikolic, S. A. Payne, Lawrence Livermore National Lab. (United States); H. Kim, L. J. Cirignano, K. Shah, Radiation Monitoring Devices, Inc. (United States) 
8852 OG Compact low-noise preamplifier for noise spectroscopy with biased photodiodes in cargo inspection systems [8852-15]

B. Benetti, Advanced Design Services Corp. (United States); W. G. J. Langeveld, Rapiscan Labs., Inc. (United States)

$8852 \mathrm{OH}$ Exploitation of geometric occlusion and covariance spectroscopy in a gamma sensor array [8852-16]

S. Mukhopadhyay, R. Maurer, R. Wolff, S. Mitchell, P. Guss, C. Trainham, National Security Technologies, LLC (United States)

8852 0I Development and first results of the Yale PIXeY two-phase xenon detector [8852-19] N. E. Destefano, Univ. of Connecticut (United States); E. Bernard, B. Edwards, Yale Univ. (United States); M. Gai, Univ. of Connecticut (United States); M. Horn, N. Larsen,

D. McKinsey, B. Tennyson, C. Wahl, Yale Univ. (United States)

\section{DEVICES II}

$88520 \mathrm{~J}$ Experimental and computational results on exciton/free-carrier ratio, hot/thermalized carrier diffusion, and linear/nonlinear rate constants affecting scintillator proportionality (Invited Paper) [8852-20]

R. T. Williams, J. Q. Grim, Q. Li, K. B. Ucer, Wake Forest Univ. (United States); G. A. Bizarri, Lawrence Berkeley National Lab. (United States); S. Kerisit, F. Gao, Pacific Northwest National Lab. (United States); P. Bhattacharya, E. Tupitsyn, E. Rowe, V. M. Buliga, A. Burger, Fisk Univ. (United States)

8852 OK Photosensor characterization for the Cherenkov Telescope Array: silicon photomultiplier versus multi-anode photomultiplier tube [8852-21]

A. Bouvier, L. Gebremedhin, C. Johnson, A. Kuznetsov, D. A. Williams, Univ. of California, Santa Cruz (United States); N. Otte, R. Strausbaugh, Georgia Institute of Technology (United States); N. Hidaka, H. Tajima, Nagoya Univ. (Japan); J. Hinton, R. White, Univ. of Leicester (United Kingdom); M. Errando, R. Mukherjee, Barnard College, Columbia Univ. (United States)

\section{NEUTRON DETECTORS}

$88520 \mathrm{M}$ Investigation of non-uniformity and inclusions in ${ }^{6}$ LilnSe $_{2}$ utilizing laser induced breakdown spectroscopy (LIBS) (Invited Paper) [8852-24]

B. Wiggins, E. Tupitsyn, P. Bhattacharya, E. Rowe, Fisk Univ. (United States); E. Lukosi, O. Chvala, The Univ. of Tennessee (United States); A. Burger, Fisk Univ. (United States) and Vanderbilt Univ. (United States); A. Stowe, Fisk Univ. (United States) and Y-12 National Security Complex (United States) 
885200 Spectral resolution in pixel detectors with single photon processing (Invited Paper) [8852-27]

C. Fröjdh, D. Krapohl, S. Reza, Mid Sweden Univ. (Sweden); E. Fröjdh, Mid Sweden Univ. (Sweden) and CERN (Switzerland); G. Thungström, B. Norlin, Mid Sweden Univ. (Sweden)

$88520 Q \quad$ Development of a high-performance detection system for the hard $\mathrm{x}$-ray astronomy (1-200 keV) based on a germanium double-sided strip detector [8852-29]

I. Mateu, J. P. Roques, O. Coeur-Joly, D. Murat, E. André, J. Landé, E. Jourdain, Institut de Recherche en Astrophysique et Planétologie, CNRS, Univ. de Toulouse (France); P. Medina, Institut de Recherche en Astrophysique et Planétologie, Univ. de Toulouse (France), Institut Pluridisciplinaire Hubert Curien, CNRS, Univ. Louis Pasteur (France), and Lab. d'Aérologie, CNRS (France); C. Mathieu, Institut Pluridisciplinaire Hubert Curien, CNRS, Univ. Louis Pasteur (France)

\section{SCINTILLATORS II}

$88520 \mathrm{~V}$ Analysis of scintillator crystal production via the edge-defined film-fed growth method [8852-33]

A. Yeckel, Univ. of Minnesota (United States); R. S. Feigelson, Stanford Univ. (United States);

J. J. Derby, Univ. of Minnesota (United States)

8852 0X Temperature behavior of CLYC/MPPC detectors [8852-35]

J. Glodo, M. McClish, R. Hawrami, P. O'Dougherty, J. Tower, A. Gueorguiev, K. S. Shah,

Radiation Monitoring Devices, Inc. (United States)

\section{CZT II}

885210 Growth and characterization of CdTeSe for room-temperature radiation detector applications [8852-38]

U. N. Roy, A. E. Bolotnikov, G. S. Camarda, Y. Cui, A. Hossain, G. Yang, R. B. James, Brookhaven National Lab. (United States); A. Fauler, M. Fiederle, Freiburger

Materialforschungszentrum (Germany); M. Sowinska, G. Hennard, P. Siffert, Eurorad S.A.

(France)

\section{POSTER SESSION}

885217 Developing a high-resolution x-ray imager using electron-multiplying (EM) CCDs [8852-17]

J. H. Tutt, D. J. Hall, A. D. Holland, N. J. Murray, The Open Univ. (United Kingdom);

J. Endicott, e2v techonologies Itd. (United Kingdom)

885218 Direction-sensitive hand-held gamma-ray spectrometer [8852-45]

S. Mukhopadhyay, National Security Technologies, LLC (United States) 
88521 A Gigahertz (GHz) hard x-ray imaging using fast scintillators [8852-47]

Z. Wang, E. Guardincerri, Los Alamos National Lab. (United States); D. D. Rathman, MIT Lincoln Lab. (United States); M. E. Azzouz, C. W. Barnes, Los Alamos National Lab. (United States); R. Berger, MIT Lincoln Lab. (United States); E. M. Bond, Los Alamos National Lab. (United States); D. M. Craig, MIT Lincoln Lab. (United States); D. Holtkamp, J. S. Kapustinsky, A. V. Klimenko, K. Kwiatkowski, R. B. Merl, C. L. Morris, J. O. Perry, Los Alamos National Lab. (United States); E. Ramberg, Fermi National Accelerator Lab. (United States); R. K. Reich, MIT Lincoln Lab. (United States); A. Ronzhin, Fermi National Accelerator Lab. (United States); K. Warner, MIT Lincoln Lab. (United States); R. T. Williams, Wake Forest Univ. (United States); R.-Y. Zhu, California Institute of Technology (United States)

8852 1B The energy dependence of the sensitivity for planar CdZnTe gamma-ray detectors [8852-48]

A. A. Zakharchenko, A. I. Skrypnyk, M. A. Khazhmuradov, A. V. Rybka, V. E. Kutny, Kharkov Institute of Physics and Technology (Ukraine); P. M. Fochuk, V. M. Sklyarchuk, Yuriy Fedkovych Chernivtsi National Univ. (Ukraine); A. E. Bolotnikov, R. B. James, Brookhaven National Lab. (United States)

$88521 \mathrm{C}$ Reasons of low charge collection efficiency in CdTe-based $\mathrm{x} / \mathrm{y}$ detectors with ohmic contacts [8852-49]

T. Aoki, Shizuoka Univ. (Japan); O. L. Maslyanchuk, L. A. Kosyachenko, Yuriy Fedkovych Chernivtsi National Univ. (Ukraine); V. A. Gnatyuk, V. Lashkaryov Institute of Semiconductor Physics (Ukraine)

8852 1D Differential thermal analysis of $\mathrm{Cd}_{0.95-x} \mathrm{Mn}_{\mathbf{x}} \mathrm{Z}_{0.05}$ Te alloys [8852-50]

V. Kopach, O. Kopach, L. Shcherbak, P. Fochuk, Yuriy Fedkovych Chernivtsi National Univ. (Ukraine); A. E. Bolotnikov, R. B. James, Brookhaven National Lab. (United States)

8852 IF Characterization of CdTe and (CdZn)Te detectors with different metal contacts [8852-52] J. Pekárek, E. Belas, R. Grill, Š. Uxa, Charles Univ. (Czech Republic); R. B. James, Brookhaven National Lab. (United States)

$88521 G \quad$ Raman analysis of $\mathbf{Z n}_{1-x} \mathbf{M n}_{\mathbf{x}}$ Te polycrystalline films [8852-53]

O. V. Klimov, D. I. Kurbatov, A. S. Opanasyuk, Sumy State Univ. (Ukraine); V. V. Kosyak, The Univ. of Utah (United States); V. Kopach, P. M. Fochuk, Yuriy Fedkovych Chernivtsi National Univ. (Ukraine); A. E. Bolotnikov, R. B. James, Brookhaven National Lab. (United States)

885211 Effect of side-surface passivation on the electrical properties of metal-Cd(Zn)Te-metal structures [8852-55]

V. Sklyarchuk, P. Fochuk, Z. Zakharuk, Yuriy Fedkovych Chernivtsi National Univ. (Ukraine);

R. Grill, Institute of Single Crystals (Czech Republic); V. Kutny, A. Rybka, D. Nakonechny,

A. Zakharchenko, Kharkov Institute of Physics and Technology (Ukraine); Ye. Nykoniuk, National Univ. of Water Management and Nature Resources Use (Ukraine); A. E. Bolotnikov, R. B. James, Brookhaven National Lab. (United States)

$88521 \mathrm{~J}$ Three-energy radiography method for uniformity control of composite materials including components with different effective atomic numbers [8852-56]

V. D. Ryzhikov, O. D. Opolonin, B. V. Grinyov, S. M. Galkin, O. K. Lysetska, Y. F. Voronkin, Institute for Scintillation Materials (Ukraine); S. A. Kostioukevitch, Institute of Semiconductor Physics (Ukraine) 
8852 1L Radioluminescence dosimetry by scintillating fiber optics: the open challenges [8852-58] I. Veronese, M. C. Cantone, Univ. degli Studi di Milano (Italy); N. Chiodini, Univ. degli Studi di Milano-Bicocca (Italy); C. De Mattia, Univ. degli Studi di Milano (Italy); M. Fasoli, Univ. degli Studi di Milano-Bicocca (Italy); E. Mones, Azienda Ospedaliera Maggiore della Carità (Italy); A. Vedda, Univ. degli Studi di Milano-Bicocca (Italy)

$88521 \mathrm{M} \quad$ Boron selenide semiconductor detectors for thermal neutron counting [8852-59]

A. Kargar, J. Tower, L. Cirignano, K. Shah, Radiation Monitoring Devices, Inc. (United States)

885210 Characterization of amorphous selenium alloy detectors for $x$-rays and high energy nuclear radiation detection [8852-61]

K. C. Mandal, A. Mehta, S. K. Chaudhuri, Univ. of South Carolina (United States); Y. Cui, M. Groza, A. Burger, Fisk Univ. (United States)

8852 IP Residual gas analysis of volatile impurities in halide precursors for scintillator crystals [8852-63]

S. Swider, S. Motakef, A. Datta, W. M. Higgins, CapeSym, Inc. (United States)

Author Index 


\title{
Conference Committee
}

\author{
Program Track Chair
}

Carolyn A. MacDonald, University at Albany (United States)

\section{Conference Chairs}

Michael Fiederle, Freiburger Materialforschungszentrum (Germany)

Arnold Burger, Fisk University (United States)

Larry Franks, Consultant (United States)

Ralph B. James, Brookhaven National Laboratory (United States)

\section{Conference Program Committee}

Toru Aoki, Shizuoka University (Japan)

Fikri Aqariden, EPIR Technologies, Inc. (United States)

Jim E. Baciak Jr., University of Florida (United States)

David B. Beach, National Nuclear Security Administration (United States)

Zane W. Bell, Oak Ridge National Laboratory (United States)

Lynn A. Boatner, Oak Ridge National Laboratory (United States)

Aleksey E. Bolotnikov, Brookhaven National Laboratory (United States)

Giuseppe S. Camarda, Brookhaven National Laboratory (United States)

Bill Cardoso, Creative Electron (United States)

Henry Chen, Redlen Technologies (Canada)

Nerine J. Cherepy, Lawrence Livermore National Laboratory

(United States)

Edith Bourret Courchesne, Lawrence Berkeley National Laboratory (United States)

Jeffrey J. Derby, University of Minnesota, Twin Cities (United States)

Kim F. Ferris, Pacific Northwest National Laboratory (United States)

Petro M. Fochuk, Yuriy Fedkovych Chernivtsi National University (Ukraine)

Jan Franc, Charles University in Prague (Czech Republic)

Fei Gao, Pacific Northwest National Laboratory (United States)

Zhong He, University of Michigan (United States)

Keitaro Hitomi, Tohoku University (Japan)

Alan Janos, U.S. Department of Homeland Security (United States)

Mercouri Kanatzidis, Northwestern University (United States)

Warnick J. Kernan, Pacific Northwest National Laboratory (United States)

Henric Krawczynski, Washington University in St. Louis (United States)

Kelvin G. Lynn, Washington State University (United States)

Krishna C. Mandal, University of South Carolina (United States)

Robert D. McLaren, Consultant (United States)

Shariar Motakef, CapeSym, Inc. (United States)

Sanjoy Mukhopadhyay, National Security Technologies, LLC (United States) 
Stephen A. Payne, Lawrence Livermore National Laboratory (United States)

Ian Radley, Kromek (United Kingdom)

Paul Sellin, University of Surrey (United Kingdom)

David J. Singh, Oak Ridge National Laboratory (United States)

Narsingh B. Singh, University of Maryland, Baltimore County (United States)

Michael R. Squillante, Radiation Monitoring Devices, Inc. (United States)

Ashley C. Stowe, Y-12 National Security Complex (United States)

Csaba Szeles, El Detection \& Imaging Systems (United States)

Sergey E. Ulin, National Research Nuclear University MEPhl (Russian Federation)

Lodewijk van den Berg, Constellation Technology Corporation (United States)

Peter E. Vanier, Brookhaven National Laboratory (United States)

Aaron L. Washington II, Savannah River National Laboratory (United States)

Session Chairs

1 Scintillators I

Nerine J. Cherepy, Lawrence Livermore National Laboratory (United States)

2 CZT I

Larry Franks, Consultant (United States)

3 Detector Materials

Krishna C. Mandal, University of South Carolina (United States)

4 Devices I

Michael Fiederle, Freiburger Materialforschungszentrum (Germany)

5 Devices II

Christer Fröjdh, Mid Sweden University (Sweden)

6 Neutron Detectors

Robert D. McLaren, Consultant (United States)

7 Devices III

Arnold Burger, Fisk University (United States)

8 Scintillators II

Ralph B. James, Brookhaven National Laboratory (United States)

9 CZT II

Aleksey E. Bolotnikov, Brookhaven National Laboratory (United States)

10 CZT III

Giuseppe S. Camarda, Brookhaven National Laboratory (United States) 


\section{Introduction}

This book contains the proceedings of the SPIE Conference on Hard X-Ray, Gamma-Ray and Neutron Detector Physics XV. The conference was held on August 26-28, 2013 in San Diego, CA. The conference was organized into technical sessions on cadmium zinc telluride (CZT), scintillators, devices, neutron detectors, and alternative semiconductor detector materials. A poster session was also provided.

The purpose of the conference was to provide a forum for scientists and engineers from the detector development and user communities to present and evaluate the most recent results on X-ray, gamma-ray, and neutron detectors and to discuss the requirements for a variety of radiation-sensing and imaging applications. The primary theme of the conference was on development of improved semiconductor and scintillator radiation detectors and imaging arrays, which combine the advantages of room-temperature operation with the ability to spectrally resolve the energies of emitted X-and gamma-rays. By eliminating the cryogen, new radiation-sensing instruments, such as spectrometers, gamma cameras and radiographic systems, can be manufactured that are portable, lightweight, easy to operate, and relatively maintenance-free. Recent research and development on detectors have resulted in measurable progress in the availability of single detectors and imaging arrays. In addition, recent reports of the material properties limiting the performance of semiconductor and scintillator detectors have provided new insights and directions to address deficiencies in the crystals and devices.

Despite the limitations on efficiency and relatively high cost of current roomtemperature semiconductor detectors and new emerging scintillators, they have been increasingly deployed in systems useful for medical diagnostics, space applications, safeguarding of nuclear materials, material identification, baggage scanning, position sensing, and gamma-ray spectroscopy. Although significant progress has occurred over recent years, there is still a pressing need to lower the cost of the detectors and to increase the efficiency of the detectors while improving their spectral performance.

A total of 60 presentations, including 20 posters, were presented at the conference. Although the number of attendees varied with the session and day of week, the attendance averaged approximately 50 people with a substantial fraction of those in attendance representing organizations outside of the U.S.

This book provides detailed documentation describing a portion of the presentations. The editors hope that it will serve as an important record of the meeting, provide an update on the status of X-ray, gamma-ray, and neutron detector technology, and serve as a useful resource for those working in the field. 
The Conference Chairs would like to thank the session chairs and members of the Conference Program Committees, who offered their time to enlist the involvement of many researchers working in the field.

Michael Fiederle

Arnold Burger

Larry A. Franks

Ralph B. James 